\title{
Brazilian refractory grade bauxite: a new alternative to refractories makers and users
}

\author{
A.L.Pereira ${ }^{1 *}$, M.A. Reis ${ }^{1}$, L. L.H.C.Ferreira ${ }^{1,2}$, P. M. Nakachima ${ }^{1}$ \\ ${ }^{\prime}$ Mineração Curimbaba, Rod. Poços de Caldas, km 10, 37701-970, Poços de Caldas, MG, Brazil \\ ${ }^{2}$ Elfusa Geral de Eletrofusão, 13872-900, S. J. da Boa Vista, SP, Brazil
}

\begin{abstract}
After two centuries of the discovery, we now know that there are several types of bauxites, in which mineralogy points to the most appropriate application. In the non-metallurgical industry, bauxites with refractory grades have been applied as raw materials in the production of high-alumina refractories for both shaped and unshaped. The increase in the cost of other sources of high-alumina raw materials has encouraged the refractory producers to find a more cost-effective substitute, such as refractory-grade calcined bauxites (RGB). Nowadays, concerns rise regarding the availability of RGB due to the continuous restrictions taking place in China, which has a $95 \%$ market share. This work presents a new RGB of high-alumina content ( $85 \%)$ from a Brazilian source in which process enabled a technology with high refractoriness.
\end{abstract}

Keywords: bauxite, refractory, raw material, phases.

\section{INTRODUCTION}

It is a well-known fact that bauxite was discovered in France near the village of 'Les Baux de Provence' in 1822 by a chemist named Berthier who found an ore which was rich in alumina and poor in iron [1]. Nowadays, it is traditionally named aluminum ore since it is composed primarily of aluminum hydroxides. The quality of the ore and the type and amount of the aluminum and other minority minerals establish the end use for the bauxite and also the process required to produce it [2]. About $95 \%$ of the bauxites in the world have end use the aluminum market, that focuses the metallurgical application. The other remaining 5\% is applied in several other segments not linked to this market as presented in the Fig. 1 [3]. Bauxites for use in high-alumina refractories production are available in discrete deposits. The term high-alumina refractories refers to refractories having alumina $\left(\mathrm{Al}_{2} \mathrm{O}_{3}\right)$ content of $47.5 \%$ or higher. This descriptive title distinguishes them from others made predominantly of clay or other aluminosilicates which have an alumina content below $47.5 \%$ [4].

Refractories - an overview: refractory materials, by definition, are supposed to be resistant to heat and are exposed to different degrees of mechanical and thermal stress and strain, corrosion/erosion from solids, liquids and gases, gas diffusion, and mechanical abrasion at various temperatures [5]. They are broadly divided into two categories: shaped (bricks and cast shapes) and unshaped (monolithic) refractories. Under these circumstances, different refractories are designed and manufactured with specific properties suitable for specific applications. The characteristic properties of each refractory category are a function of both their raw materials and the methods used

*andre.pereira@curimbaba.com.br

(D) https://orcid.org/0000-0001-8083-0423

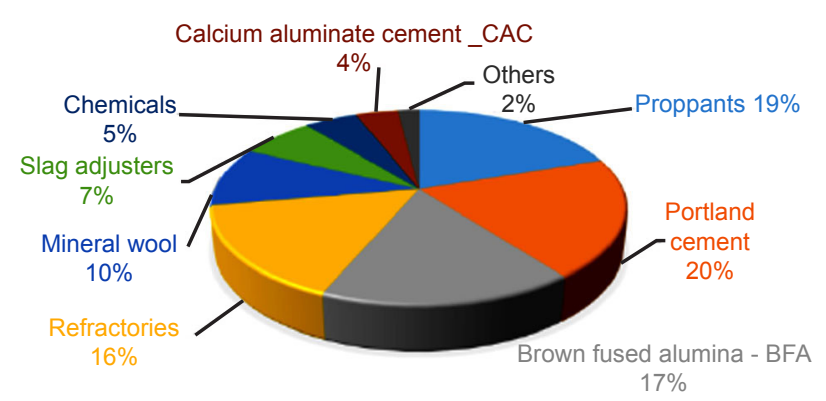

Figure 1: Non-metallurgical world markets for bauxites (adapted from [3]).

to manufacture the refractory products. Most refractory materials are supplied as preformed shapes, but the monolithic category has evolved and grown significantly in the past 40 years, becoming in many applications, the refractories of choice because of enhanced performance and ease of installation [6]. In addition, the proportion of unshaped refractories within the overall balance in leading countries has reached 50\%-60\% [07]. In this category, it stands out the refractory castables which are premixed combinations of refractory aggregates, matrix components, bonding agents, and admixtures. At the point of installation, the castable is mixed with a liquid (typically water) and vibrated, poured, pumped, or pneumatically shot into place to form a refractory shape or structure that becomes rigid because of hydraulic or chemical setting. The refractory aggregates are considered the 'skeleton' of the castable and account for the largest amount of the formulation, being proportioned to achieve the desired packing and particle size distribution. A wide variety of aggregates is available and castable formulations can be based on only one type or a combination of them according to the properties demanded $[6,7]$. In this scenario, the highalumina materials account for $70 \%$ of world production and quite often the main raw material for producing them is the refractory grade bauxites [7]. 
Refractory grade bauxites: generally non-plastic, physical properties of crude bauxites vary widely, depending on the type, nature of deposit and tectonic history. In texture, some bauxites are soft, friable and structureless; some are hard, dense and pisolitic; still, others are porous but strong, or are stratified. Color may be pink, cream, red, brown, yellow or gray, depending upon the amount of impurities, particularly iron oxide. The alumina constituents have been identified as gibbsite (trihydrate), boehmite and diaspore (monohydrates), alone or in mixtures. The minerals kaolinite, hematite, magnetite, goethite, siderite, and quartz may be present as common impurities. Additionally, rutile, anatase, and zircon may also be present. Due to this variety of minerals and the different concentration of each, the specific gravity varies from 2.45 to $3.25 \mathrm{~g} / \mathrm{cm}^{3}$, and the material can melt at $1800{ }^{\circ} \mathrm{C}$ or higher [8]. Such refractoriness is associated to the alumina content, and more specifically to the amount of corundum generated during the calcination, once this mineralogical phase has the highest melting point among the phases formed [9]. Although refractory-grade calcined bauxites (RGB) usually have high refractoriness they usually present lower refractoriness under load $\left(1450-1550{ }^{\circ} \mathrm{C}\right)$, even if compared with other raw materials from the aluminasilica system with lower content in alumina. This decrease in refractoriness is connected to the presence of the glassy phase in the microstructure due to the impurities which works like fluxing agents, specially the alkaline compounds. In addition to the reduction of the temperature of service, the glassy phase formation lowers the corrosion resistance, facilitates the slag attack and increases the mechanisms of creep. Besides, the glassy phase distribution among the solid phases is more important on the refractoriness under load than its amount [10]. Other refractory phase desired after heat treatment is mullite which promotes high thermal shock, creep resistance and improves the mechanical strength of the refractory. If the mullite crystallites are acicular shaped they yield a three-dimensional network preventing shearing and deformation at high temperatures [11].

Depending on the geologic origin of the bauxite ore, the iron and titanium oxides content in the RGBs can vary widely. Iron oxide has been associated with the reduction of the softening point and consequently the refractoriness of the refractory piece, but if iron is not available in the reduced form, the $\mathrm{Fe}^{3+}$ ions can be incorporated as a solid solution into the crystalline structure of some mineralogical phases such as corundum and mullite. Otherwise, titanium oxide easily reacts with aluminum oxide forming the phase tialite $\left(\mathrm{Al}_{2} \mathrm{TiO}_{5}\right)$, which in spite of having a high melting point $\left(1850{ }^{\circ} \mathrm{C}\right)$ it does not present a good mechanical strength and thermal stability. In intermediate temperatures (750 to $1350{ }^{\circ} \mathrm{C}$ ) tialite can decompose chemically itself, impairing the high-temperature performance of the refractory [12]. Likewise, a highly anisotropic thermal expansion of its crystals can result in microcracks and lead to the rupture of the refractory [13].

Generally, RGBs have adequate cold and hot compressive strength and the aggregates resist cracking, spalling, and chemical and physical reaction with furnace charges. Due to these properties, bauxite-containing refractories are commonly used in: linings of rotary kilns for the manufacture of Portland cement, dolomite and lime; combustion chamber linings for boilers; in the ceramic industry as glass tank blocks, furnace parts, regenerator walls and checkers; in the steel ladles metals industry for center walls of zinc distillation furnaces, bottoms of malleable iron furnaces, water-cooled ports of basic open-hearth furnaces, walls and floors of aluminum holding furnaces; and in other types of furnaces where the ash is highly corrosive to brick [8]. More specifically in shaped refractories, refractory grade bauxites find uses in different classes of high-alumina bricks as shown in Table I.

Selecting the most suitable refractory materials to prolong service life and make a process more cost-effective is now more critical than ever in today's competitive environment. Consequently, to find alternative sources of price competitive high-alumina raw materials is challenging, especially because raw materials substitution is not a quick process, with quality and product testing involved. In most cases, refractory properties can be predicted from the results of appropriate tests; for others, knowledge and experience predict the refractory properties where direct tests are not available. In general, the basic physical properties can often indicate whether a refractory material can be used for intended applications. Nevertheless, the differences between the 'good' and 'not-as-good' products are usually not revealed in standard tests alone. Further tests or experiences are required to understand the reasons why one product may be better than another [14]. Between this and that, the necessity of good and cheaper substitutes encourages the research and development of alternative industrial minerals. In this paper

Table I - Classes of high-alumina bricks and the main raw materials applied (adapted from [14]).

\begin{tabular}{|c|c|c|c|}
\hline Brick class & Usual terminology & Prime phases & Raw materials \\
\hline$<50 \% \mathrm{Al}_{2} \mathrm{O}_{3}$ & Fireclay (chamotte) & Mullite and free-silica/glass & Fireclay minerals \\
\hline $50-60 \% \mathrm{Al}_{2} \mathrm{O}_{3}$ & $\begin{array}{c}\text { Sillimanite, } \\
\text { andalusite, kyanite }\end{array}$ & Mullite and glass/free-silica & $\begin{array}{c}\text { Alumina minerals \& fireclay; bauxite } \\
\text { \& clay }\end{array}$ \\
\hline $70 \% \mathrm{Al}_{2} \mathrm{O}_{3}$ & Mullite & Mullite, corundum and glass & Bauxitic clay; calcined bauxite $\&$ clay \\
\hline $80-85 \% \mathrm{Al}_{2} \mathrm{O}_{3}$ & Bauxite & Corundum, mullite and glass & Calcined bauxite \\
\hline$>90 \% \mathrm{Al}_{2} \mathrm{O}_{3}$ & Alumina & Corundum, mullite and glass & Tabular or fused alumina aggregates \\
\hline
\end{tabular}


the authors present the processing and the properties of a Brazilian refractory grade bauxite as a feasible substitute raw material for high-alumina refractories manufacturing, comparing its characteristics with a traditional product from China.

\section{MATERIALS AND METHODS}

The Brazilian refractory grade bauxite production begins with a high-alumina bauxite ore from Barro Alto Complex (BAC) in the state of Goiás, Brazil. These bauxites were recently discovered and they were originated from a process of bauxitisation in anorthosites [15]. Before any process took place, the bauxite ores were selected and the chemical and mineralogical analyses were performed to set the correct blending, aiming the production of calcined bauxite with high-alumina refractory grade. Fig. 2 and Table II present, respectively, a typical mineralogical and chemical quantification analysis about the composition of a bauxite extracted from BAC.

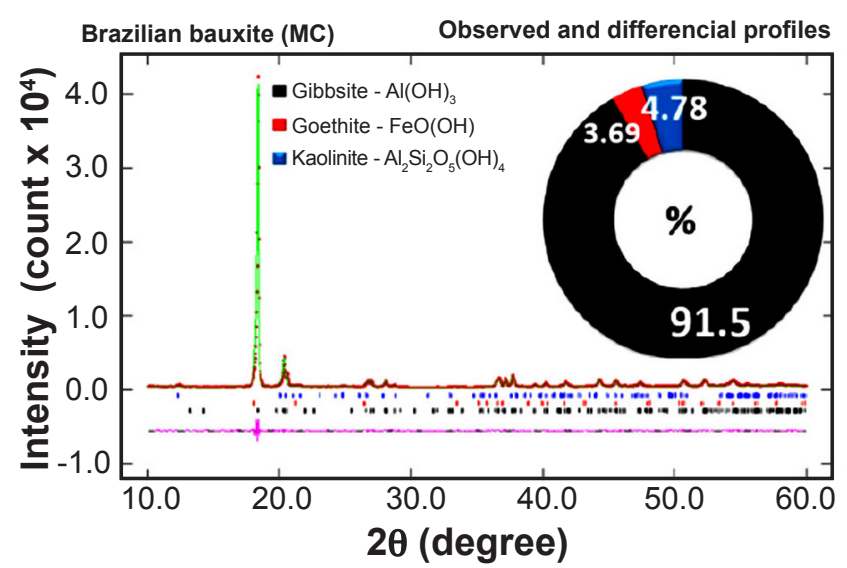

Figure 2: X-ray diffraction data: Rietveld graphic and mineralogical composition for crude bauxite used in the production of Brazilian refractory grade bauxite.

Table II - Chemical composition (wt\%) of crude bauxite from Barro Alto Complex.

$\begin{array}{lllllll}\text { Crude bauxite } \mathrm{Al}_{2} \mathrm{O}_{3} & \mathrm{SiO}_{2} & \mathrm{Fe}_{2} \mathrm{O}_{3} & \mathrm{TiO}_{2} & \mathrm{RO}^{\mathrm{a}} & \mathrm{R}_{2} \mathrm{O}^{\mathrm{b}} & \mathrm{LOI}^{\mathrm{c}}\end{array}$ \begin{tabular}{llllllll}
\hline $\mathrm{BAC}-\mathrm{MC}$ & 59.7 & 3.53 & 3.88 & 0.37 & 0.07 & 0.01 & 32.5 \\
\hline
\end{tabular}

${ }^{a}-\mathrm{MgO}+\mathrm{CaO} ;{ }^{b}-\mathrm{K}_{2} \mathrm{O}+\mathrm{Na}_{2} \mathrm{O} ;{ }^{c}-$ loss on ignition $@ 1100{ }^{\circ} \mathrm{C} / 2 \mathrm{~h}$.

After selection of the crude bauxite, the first step of the manufacturing process was to promote the drying of this raw material. After the drying process, the bauxite was homogenized in a correct blend to adjust the silica and alumina content. The mixture was milled and pelletized to form homogeneous aggregates or granules with water addition. The granules were dried, calcined and sintered using a rotary kiln, with temperatures of processing around $1650{ }^{\circ} \mathrm{C}$. The run of kiln product was cooled through a rotary cooler, crushed using roll crushers and sieved in vibratory screeners to produce the size fraction desired. Fig. 3 presents the flowchart of the refractory grade bauxite process developed.

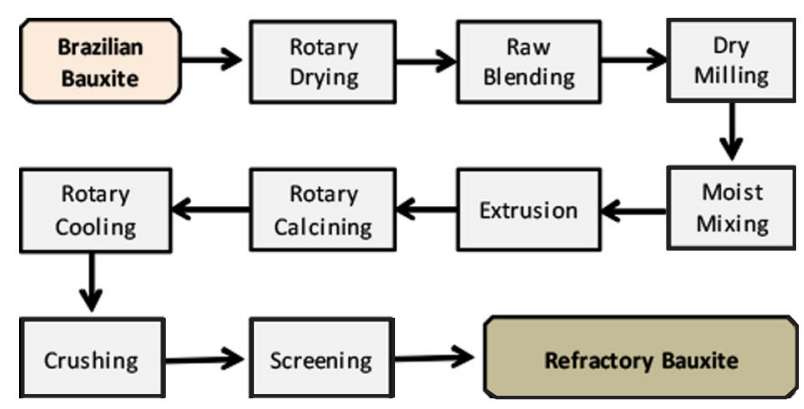

Figure 3: Flowchart for Brazilian refractory grade bauxite manufacturing.

The refractory bauxite produced was chemically analyzed by X-ray fluorescence technique in a sequential wavelength dispersive spectrometer (XRF 1800, Shimadzu) after sample preparation by fusion method in a high-frequency induction machine (HA-HF 16/2, Herzog). The mineralogy was evaluated by X-ray diffractometry in a vertical $\theta-2 \theta$ diffractometer (XRD 6000, Shimadzu), operating with a source of $\mathrm{CuK} \alpha$ radiation (power $=40 \mathrm{kV}, 30 \mathrm{~mA}$ ) in a step scan mode $\left(\mathrm{step}=0.02^{\circ} 2 \theta\right.$, time $=2 \mathrm{~s}$, scan range $=$ 15 to $80^{\circ} 2 \theta$ ). After mineralogical phase identification, the Rietveld method (RM) was applied for quantitative phase analysis (QPA) and microstructural evaluation [16, 17]. The microstructure of the grains was also evaluated by scanning electron microscopy (SEM) in a benchtop microscope (Phenom-World Pro-X, ThermoFisher). The apparent porosity of the grains and the bulk density were measured using a hydrostatic scale following the NBR 8592 standard [18]. Finally, the refractoriness was determined by the pyrometric cone equivalent (PCE - ASTM C24) [19] and firebricks were prepared using calcined refractory bauxite (grain size distribution from $44 \mu \mathrm{m}$ to $9.5 \mathrm{~mm}$ ) shaped in a low cement castable (LCC) formulation, bonded by calcium aluminate cement $\left(70 \% \mathrm{Al}_{2} \mathrm{O}_{3}\right)$, in a matrix of microsilica and tabular alumina, and fired at $1000{ }^{\circ} \mathrm{C} / 5 \mathrm{~h}$, for cold compressive strength (CCS) and refractoriness under load test (RUL - ASTM C16) [20]. The tests and analyses on the Brazilian refractory grade bauxite were reproduced and compared with one commercial Chinese calcined refractory bauxite, since China dominates the refractory grade bauxite market and it is in charge of $95 \%$ of the world supply [21].

\section{RESULTS AND DISCUSSION}

An evaluation of the aspect of the Brazilian refractory grade bauxite grains (MC) shows a high homogeneity in shape and color tones whereas, for the Chinese sample $(\mathrm{CH})$, the same homogeneity was not observed since the grains presented different color tones and shapes. Indeed, the homogeneity noticed in the Brazilian sample was strictly associated with the process developed. Fig. 4 illustrates the aspect for both samples studied, presenting them side by side to stand out the contrast among the grains in each sample. This simple comparison is important because traditionally Chinese refractory bauxites present different 
colors, where one can see a blend of different aggregates with different chemical and physical compositions, and the product (blend) has an average value of oxide content. The grains individually have their own composition, pore distribution and non-uniform microstructure. This fact is due to the absence of technologies to promote a good pre-firing homogenization and the use of shaft kilns in many plants [7]. In a study splitting the Chinese bauxites by colors (yellow, gray and black), it was shown notorious difference in the chemical composition and mainly in the physical properties, in which the black bauxites had the greatest density (3.42 $\left.\mathrm{g} / \mathrm{cm}^{3}\right)$ and the lowest porosity $(5.0 \%-7.5 \%)$, and the gray bauxites showed the lowest density $\left(2.99 \mathrm{~g} / \mathrm{cm}^{3}\right)$ and the greatest porosity $(15 \%-20 \%)$ [7].

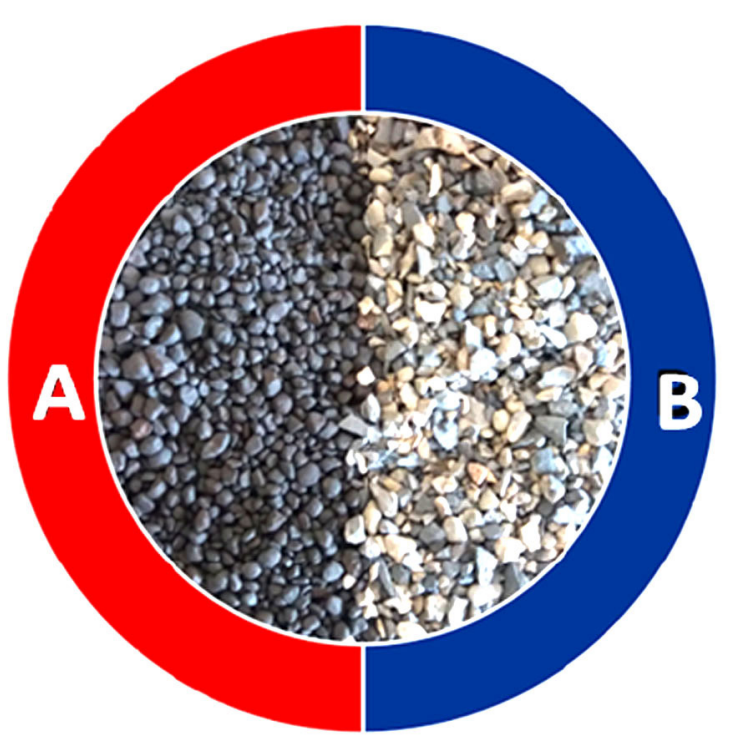

Figure 4: Aspect of refractory grade bauxites: A) Brazilian - MC; B) Chinese - $\mathrm{CH}$.

The chemical composition of the refractory grade bauxites is presented in Table III. The prime difference between the Brazilian refractory grade bauxite and the Chinese one was the amount of iron and titanium oxides, in which Brazilian sample was richer in iron $(3.80 \%)$ and the Chinese sample was richer in titanium (3.59\%). The typical values for the concentration of these oxides were less than $6 \%\left(\mathrm{Fe}_{2} \mathrm{O}_{3}+\mathrm{TiO}_{2}\right)$. Regarding the physicochemical characteristics (Table IV) all samples presented low apparent porosity $(<8 \%)$, low water absorption $(<3 \%)$ and high bulk density $\left(>3.0 \mathrm{~g} / \mathrm{cm}^{3}\right)$. The mineralogical analysis (Table $\mathrm{V}$, Fig. 5) was in compliance with the chemical composition (Table III), since they showed corundum and mullite for all samples and tialite and rutile only for the Chinese bauxites. The higher content in $\mathrm{TiO}_{2}$ for the Chinese sample can be considered harmful due to the tialite formation in calcined grains [22, 23].

Corundum synthesis from gibbsite involves a series of transformations preventing fast growth of corundum crystallites. Gibbsite starts losing combined water at about $500{ }^{\circ} \mathrm{C}$. Combined water is driven off in two main stages:
Table III - Chemical composition (wt\%) of refractory grade bauxites.

\begin{tabular}{ccccccc}
\hline $\mathrm{RGB}$ & $\mathrm{Al}_{2} \mathrm{O}_{3}$ & $\mathrm{SiO}_{2}$ & $\mathrm{Fe}_{2} \mathrm{O}_{3}$ & $\mathrm{TiO}_{2}$ & $\mathrm{RO}^{\mathrm{a}}$ & $\mathrm{R}_{2} \mathrm{O}^{\mathrm{b}}$ \\
\hline $\mathrm{MC}$ & 84.8 & 8.06 & 3.80 & 1.63 & 0.39 & 0.14 \\
$\mathrm{CH}$ & 86.5 & 7.01 & 1.60 & 3.59 & 0.45 & 0.15 \\
\hline${ }^{a}-\mathrm{MgO}+\mathrm{CaO}^{b}-\mathrm{K}_{2} \mathrm{O}+\mathrm{Na}_{2} \mathrm{O}$. & & & &
\end{tabular}

Table IV - Physicochemical properties of refractory grade bauxites.

\begin{tabular}{cccc}
\hline RGB & $\begin{array}{c}\text { Apparent } \\
\text { porosity (\%) }\end{array}$ & $\begin{array}{c}\text { Water } \\
\text { absorption }(\%)\end{array}$ & $\begin{array}{c}\text { Bulk density } \\
\left(\mathrm{g} / \mathrm{cm}^{3}\right)\end{array}$ \\
\hline $\mathrm{MC}$ & 7.88 & 2.53 & 3.12 \\
$\mathrm{CH}$ & 6.38 & 2.12 & 3.01 \\
\hline
\end{tabular}

Table V - Mineralogical composition (wt \%) of refractory grade bauxites.

\begin{tabular}{cccc}
\hline Mineral & Formula & $\mathrm{MC}$ & $\mathrm{CH}$ \\
\hline Corundum & $\mathrm{Al}_{2} \mathrm{O}_{3}$ & 78.8 & 79.7 \\
Mullite & $\mathrm{Al}_{4+2 \mathrm{x}} \mathrm{Si}_{2-2 \mathrm{x}} \mathrm{O}_{10-\mathrm{x}}$ & 19.4 & 15.4 \\
Rutile & $\mathrm{TiO}_{2}$ & - & 0.50 \\
Tialite & $\mathrm{Al}_{2} \mathrm{TiO}_{5}$ & - & 4.40 \\
Hematite & $\mathrm{Fe}_{2} \mathrm{O}_{3}$ & 1.80 & - \\
\hline
\end{tabular}

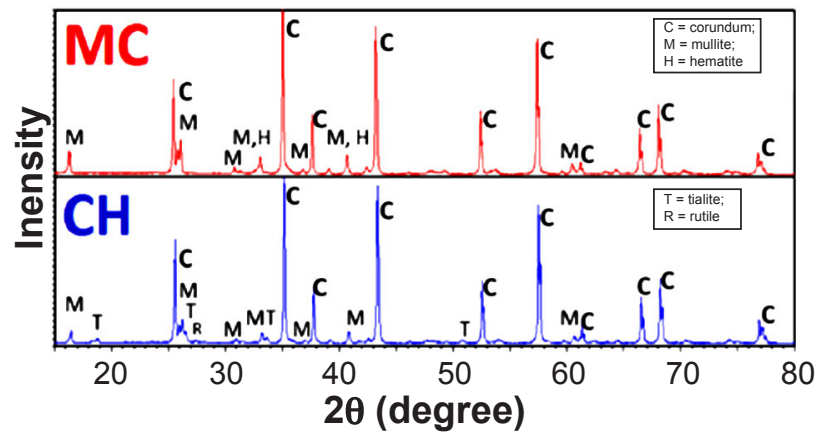

Figure 5: X-ray diffraction patterns for RGBs: $\mathrm{MC}$ - Brazilian; $\mathrm{CH}$ - Chinese.

gibbsite (trihydrate) converts at about $250^{\circ} \mathrm{C}$ to monohydrate with loss of 2 moles of water, and most of the remainder is driven off at around $550^{\circ} \mathrm{C}$. Practical dehydration is attained at about $950{ }^{\circ} \mathrm{C}$ [14]. Small crystallites of alumina are able to react with silica from the liquid phase, generating a solid solution of mullite rich in alumina. Chinese refractory bauxite does not undergo these transformations since the corundum formation during the firing process from the dry bauxite has diaspore (monohydrate) as an aluminum source. The transformation of diaspore in mullite during the firing process is fast and occurs under a lower temperature if compared with gibbsite. The diaspore transition to corundum is direct and does not go through many alumina metastable transitions during the thermal transformation sequence until achieving the stable phase equilibria [24]. This straight transformation promotes the growth of these crystallites and 
inhibits the reactivity with silica (glassy phase). Additionally, the excess of titanium oxide in the Chinese raw material generates the phase tialite during the calcination process as observed in Table V (tialite $=4.40 \%$ ). A remaining amount is presented in the rutile form (rutile $=0.50 \%$ ), probably related to the lack of temperature in the furnace/material gradient or the tialite decomposition due to its instability during the cooling from the firing [12]. The good percentage of silica arising from the kaolinite phase in the Brazilian bauxite after the proper blending promoted an optimum amount of mullite (mullite $=19.4 \%$ ), allowing the incorporation of titanium and iron inside the crystalline structure through the solid solution formation, inhibiting the tialite formation and allowing only a small amount of crystalline iron oxide in the hematite form (hematite $=1.80 \%$ ). A similar mechanism for mullite formation happens in shaped refractories, for instance, promoting good characteristics to the refractory. In firebricks application using fireclays as a binder agent, the mullite formed at the surfaces of the grains of bauxite acts as a protective layer, retarding or preventing further reaction between the corundum on the interior of the grains and the free-silica formed during the firing treatment from the fireclay between the grains. The same exists when fused alumina (artificial corundum) is added to or is bonded by fireclay in the manufacture of high-alumina bricks. When the refractory is fired, a protective layer of mullite forms at the surfaces of the corundum grains by combining with free-silica released by recrystallization of the fireclay [25]. A flowchart to explain the main reactions taking place in the production of the Brazilian refractory grade bauxite is proposed in Fig. 6.

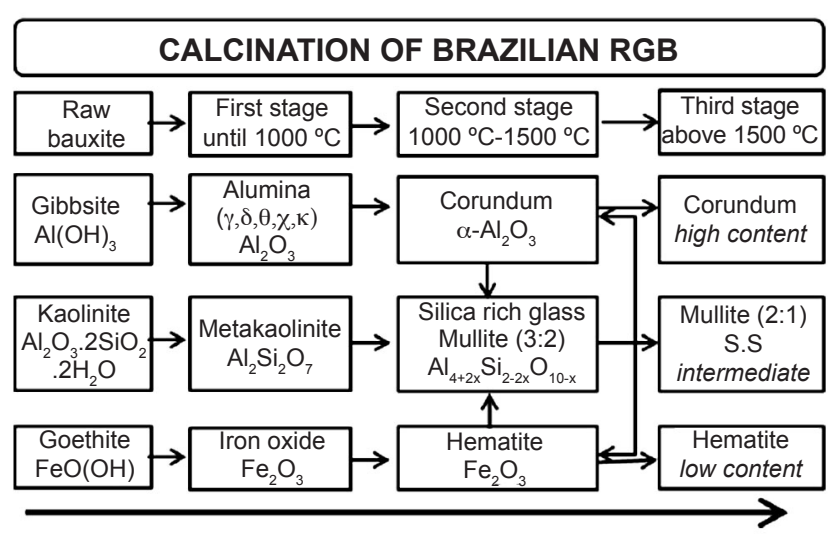

Figure 6: Firing reaction sequence of solid state in Brazilian RGB.

A survey of the literature data shows that mullite incorporates up to about $12 \% \quad \mathrm{Fe}_{2} \mathrm{O}_{3}$ while titanium solubility ranges between about $2 \%$ and $6 \% \mathrm{TiO}_{2}$, depending on the synthesis conditions [26]. These incorporations cause strong expansions in the unit cell and were already studied in refractory grade bauxites by Schneider and Wohlleben [27] that found a linear correlation between the impurity incorporation (sum of iron and titanium) and the unit cell parameters, allowing an estimation of $\mathrm{Fe}_{2} \mathrm{O}_{3}$ and $\mathrm{TiO}_{2}$ amounts inside the crystal structure of mullite from the cell parameters. Those researchers used bauxites with $\mathrm{Fe}_{2} \mathrm{O}_{3}+\mathrm{TiO}_{2}$ ranging from $0.43 \%$ to $6.9 \%$ [27]. Thus, the results from that reference were plotted and the lattice edge 'b' of mullite obtained by Rietveld refinement was added into the graphic, using the linear equation. Fig. 7 shows that a good amount of impurities was incorporated into mullite, with greater value for the MC sample (7.74\%). Additionally, Brazilian refractory grade bauxite presented the largest unit cell parameters for corundum and mullite after Rietveld refinement, considering a comparison with the pure phases and Chinese bauxite. These results are shown in Fig. 8, proving the higher incorporation of iron and titanium in the Brazilian bauxite.

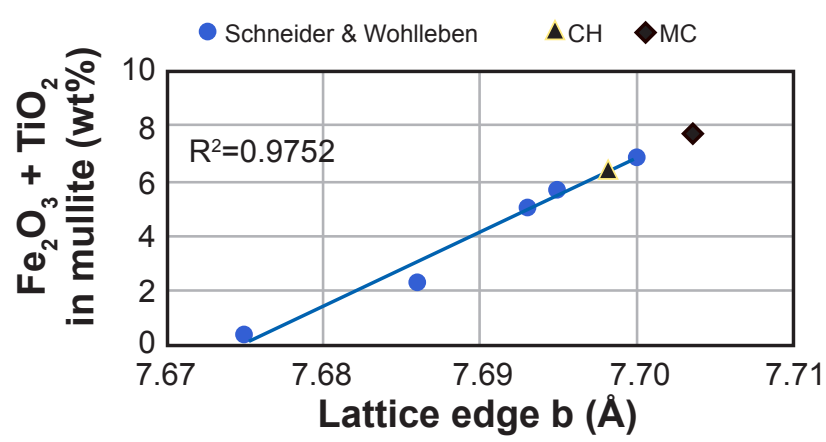

Figure 7: Correlation between the lattice edge $b$ and the $\mathrm{Fe}_{2} \mathrm{O}_{3}+\mathrm{TiO}_{2}$ content in solid solution of mullite. Schneider \& Wohlleben Guyanese bauxite; MC - Brazilian bauxite; $\mathrm{CH}$ - Chinese bauxite (adapted from [27]).

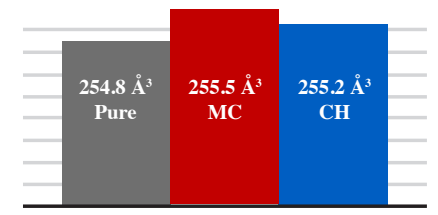

Corundum

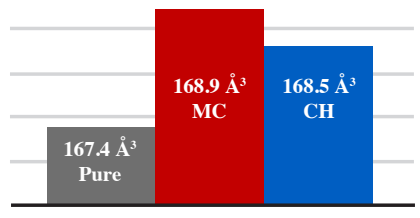

Mullite
Figure 8: Unit cell volume refined for the main phases of the refractory grade bauxites: Pure - pattern phase; MC - phase in Brazilian bauxite; $\mathrm{CH}$ - phase in Chinese bauxite.

It is interesting to study the relationship of the impurities with the microstructure of the material because it can lead to the understanding of its effect in the performance of the refractory. The solid solution formation can change the morphology of the crystallites. For instance, acicular mullite is obtained from pure oxides adding iron oxide in the precursors [28], whereas titanium dioxide addition promotes rounded crystallites [29]. For the sake of these different influences in the morphology of the mullite crystallites, the scanning electron microscopy (SEM) was applied to examine the shape of these crystallites in the matrix of corundum for the Brazilian sample. Fig. 9 shows the image obtained in a microscope operated under $10 \mathrm{kV}$, $\mathrm{CeB}_{6}$ electron source and backscattered electron detector (BSD). The microstructure of RGBs is mainly composed of corundum grains surrounded by a matrix which may contain, among other phases, mullite, tialite, glassy phase, and iron either as oxide compounds or in solid solution [9]. The 
image shown in Fig. 9 presents acicular mullite (elongated prismatic crystallites), proving the importance of the proper iron content in the Brazilian bauxite. These acicular-shaped crystallites are desired in the matrix of the refractory bauxite to assure good thermomechanical properties. Additionally, the absence of a glassy phase surrounding the crystallites as a whole is observed (i.e., there are only a few small isolated and well-spread areas of liquid phase). Such a homogeneous microstructure can ensure a stable performance for hightemperature technology.

The refractoriness of the bauxites was initially determined in ground samples and the cold compressive strength of the refractory bricks shaped with the bauxites as aggregate in their LCC formulations was achieved, with both measurements resulting in satisfactory results for high-alumina refractories (Table VI). A simple definition of refractoriness is that the material does not melt or deform (shrink) under prolonged service in the furnace environment. PCE values are used to classify aluminosilicate refractories being an effective method to give an indication of the refractoriness of a material in an unstressed situation. It is affected by the presence of impurities which reduce the PCE value, by acting as fluxes. Determination of the PCE can ensure that a refractory selected for a particular application is operating well below the onset of melting, identifying variations, mining control, and developing raw material specifications. The cold compressive strength is a combined measure of the refractory brick for the strength of the grains and also of the bonding system.

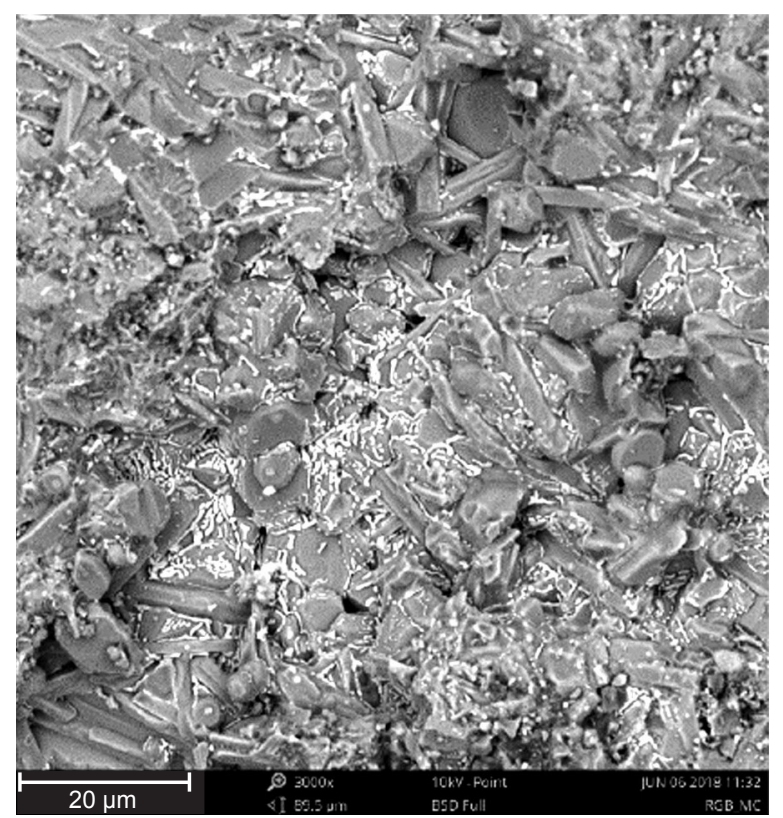

Figure 9: Micrograph (SEM-BSE) of the Brazilian refractory grade bauxite.

Refractoriness under load (RUL) is the ability of a material to withstand specific conditions of load, temperature, and time. This is dependent on the softening point and the amount of glass or melt phase within the refractory
Table VI - Characterization properties of RGBs and firebricks having RGB as aggregate.

\begin{tabular}{ccc}
\hline RGB & $\begin{array}{c}\text { Deformation } \\
\text { temperature* }\left({ }^{\circ} \mathrm{C}\right)\end{array}$ & $\begin{array}{c}\text { Cold compressive } \\
\text { strength (MPa) }\end{array}$ \\
\hline $\mathrm{MC}$ & $>1804$ & 52.7 \\
$\mathrm{CH}$ & $>1804$ & 45.3 \\
\hline *PCE - ground sample $(-70$ mesh); Orton cone $>36$.
\end{tabular}

system. A specified load is applied to the specimen, and the material is then heated to the maximum test temperature [30]. The RUL test was performed in two firebricks for each bauxite ( $\mathrm{MC}$ and $\mathrm{CH}$ ) following the heating pattern presented in Fig. 10. The firebricks prepared with MC refractory bauxite supported the load of $25 \mathrm{psi}(172 \mathrm{kPa})$ in a furnace at $1600{ }^{\circ} \mathrm{C} / 1.5 \mathrm{~h}$, without cracking or rupture, while the firebricks prepared with $\mathrm{CH}$ refractory bauxite could not withstand these conditions and were destroyed by shear fracture during the test run. Fig. 11 shows the bricks produced with $\mathrm{MC}$ and $\mathrm{CH}$ aggregates after the RUL test. It is visible the difference in performance. Although the Chinese samples $(\mathrm{CH})$ presented higher alumina content and lower porosity, their compressive strengths were lower than MC samples and could not hold their integrities in the RUL test. The heterogeneity of refractory bauxites impairs the thermomechanical behavior of the refractories since specific aggregates with lower alumina content and higher impurities deform at a lower temperature [10]. These results showed the importance of a continuous and homogeneous matrix with corundum as primary phase surrounded by acicular-shaped mullite crystallites forming a tough network

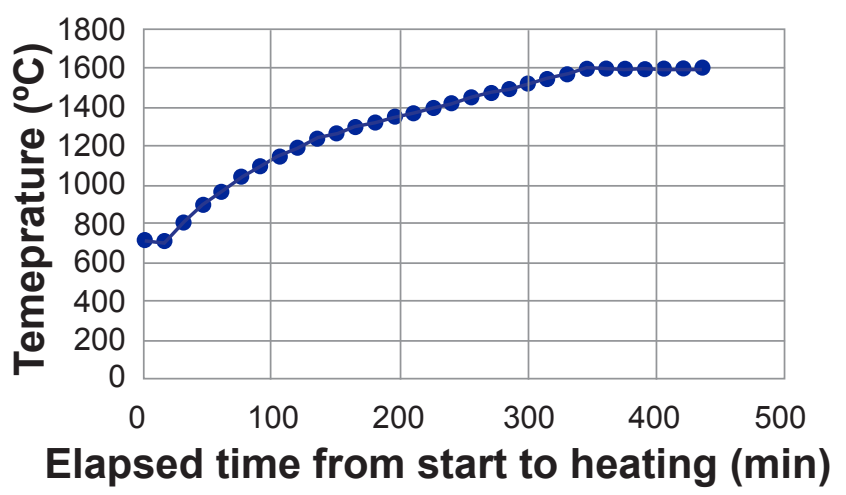

Figure 10: Time-temperature cycle used in the RUL evaluation (adapted from [20]).

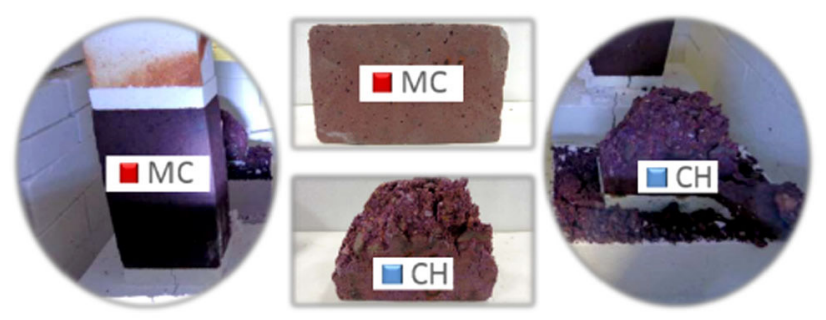

Figure 11: Images of the specimens after hot load test: MC Brazilian; $\mathrm{CH}$ - Chinese. 
that avoid a crack propagation. The homogeneity in the microstructure was a result of the fine blending process of the Brazilian refractory grade bauxite. These best results in the refractoriness under load test for the samples prepared with Brazilian refractory grade bauxite had also a relation with the absence of the phase tialite and the glassy phase surrounding the crystallites individually as a whole.

\section{CONCLUSIONS}

The Brazilian refractory grade bauxite has been presented as an excellent alternative to high-alumina refractory producers. The good characteristics of the raw bauxite allied with the processing route employed led to the manufacturing of dense homogeneous aggregates with low porosity $(7.88 \%)$. Noteworthy is the microstructural homogeneity with corundum as the major phase (78.8\%), the non-formation of tialite and the absence of glassy phase surrounding the crystallites in the matrix, besides a suitable concentration of mullite (19.4\%) in acicular-shaped crystallites.

\section{ACKNOWLEDGMENTS}

Special thanks to the Curimbaba Group for supporting this development and Nova Analítica which kindly made available its facilities and staff for SEM analysis.

\section{REFERENCES}

[1] J. Régnier, in: "Essential readings in light metals", D. Donaldson, B.E. Raahauge (Ed.), Miner., Metals Mater. Soc., Springer, Cham (2016) 3.

[2] Roskill Inf. Serv., "Bauxite - non-metallurgical: global industry, markets \& outlook to 2021", $9^{\text {th }}$ ed. (2016).

[3] J. Roberts, in: $22^{\text {nd }}$ Bauxite \& Alumina Conf., Miami (2016).

[4] Handbook of refractory practice, Harbison Walker Refr., Moon Township (2005) 7.

[5] S. Banerjee, in: "Refractories handbook", C.A. Schacht (Ed.), Marcel Dekker, New York (2004) 1.

[6] L. Krietz, in: "Refractories handbook", C.A. Schacht (Ed.), Marcel Dekker, New York (2004) 259.

[7] Y.E. Pivinski, P.V. Dyakin, V.A. Perepelitsyn, Refract. Ind. Ceram. 56, 4 (2015) 344.

[8] Ceram. Ind., "Materials handbook" (2018) <http://www. ceramicindustry.com>, ac. 08/31/2018.
[9] P. Sepúlveda, A.R. Studart, V.C. Pandolfelli, C.E.B. Neves, InterCeram 48, 6 (1999) 398.

[10] A. Caballero, F.J. Valle, S. de Aza, S. Castillo, Ceram. Int. 11, 2 (1985) 45.

[11] X. Zhong, G. Li, Ceram. Int. 7, 2 (1981) 65.

[12] A. Tsetsekou, J. Eur. Ceram. Soc. 25, 4 (2005) 335.

[13] P. Jeschke, I. Elstner, D. Grimm, S. Pischek, in: UNITECR Congr., S. Paulo (1993) 843.

[14] D.A. Brosnan, in: "Refractories handbook", C.A. Schacht (Ed.), Marcel Dekker, New York (2004) 79.

[15] F.S. Oliveira, A.F.D.C. Varajão, C.A.C. Varajão, B. Boulangé, N.S. Gomes, Geoderma 167-168 (2011) 319.

[16] A.C. Larson, R.B. Von Dreele, "General structure analysis system (GSAS)", Los Alamos Nat. Lab. Rep. LAUR 86-748 (2004).

[17] B.H. Toby, J. Appl. Crystallogr. 34 (2001) 210.

[18] Ass. Bras. Normas Técn., "Dense granulated refractory materials - determination of bulk density, absorption and apparent porosity - test methods - ISO 8592:2012", ABNT, Rio Janeiro (2013).

[19] ASTM C24, "Standard test method for pyrometric cone equivalent (PCE) of fireclay and high alumina refractory materials, ASTM Int., West Conshohocken (2018).

[20] ASTM C16, "Standard test method for load testing refractory shapes at high temperatures", ASTM Int., West Conshohocken (2018).

[21] M. O’Driscoll, in: 61 ${ }^{\text {st }}$ Int. Colloq. Refract., Aachen (2018).

[22] C. Pascoal, V.C. Pandolfelli, Cerâmica 46, 298 (2000) 76.

[23] C. Pascoal, V.C. Pandolfelli, Cerâmica 46, 299 (2000) 131.

[24] P.S. Santos, H.S. Santos, S.P. Toledo, Mater. Res. 3, 4 (2000) 104.

[25] Handbook of refractory practice, Harbison Walker Refr., Moon Township (2005) 14.

[26] H. Schneider, in: "Mullite", H. Schneider, S. Komarneni (Ed.), Wiley-VCH, Weinheim (2005) 70.

[27] H. Schneider, K. Wohlleben, Ceram. Int. 7, 4 (1981) 130.

[28] S.M. Johnson, J.A. Pask, Am. Ceram. Soc. Bull. 61, 8 (1982) 838.

[29] J.S. Moya, C. Baudin, J. Am. Ceram. Soc. 67, 7 (1984) C134.

[30] S. Baxendale, in: "Refractories handbook", C.A. Schacht (Ed.), Marcel Dekker, New York (2004) 435.

(Rec.01/09/2018, Rev. 02/11/2018, Ac.07/11/2018) 